\title{
DISCURSOS SOBRE ASSÉDIO SEXUAL DE RUA E SEU DIÁLOGO COM O CONTRATO SEMIÓTICO DE RESPONSABILIZAÇÃO DA VÍTIMA
}

\author{
THE DISCOURSES ABOUT SEXUAL STREET HARASSMENT AND ITS \\ DIALOGUE WITH THE SEMIOTIC CONTRACT OF VICTIM'S BLAME
}

Adriana Tulio BAGGIO

Centro de Pesquisas Sociossemióticas (PUC-SP)

\begin{abstract}
Resumo: $\mathrm{O}$ assédio sexual de rua é um tipo de violência contra a mulher cujo enfrentamento é dificultado, entre outros fatores, pela falta de dados. Essa carência foi pouco minorada pela promulgação da lei de importunação sexual em 2018. Antes da lei, uma das iniciativas que se propuseram a dar visibilidade aos casos de assédio no Brasil foi o mapa Chega de Fiu-Fiu, operante de 2014 a 2019. Vítimas ou testemunhas de assédio podiam registrar uma ocorrência, indicar a localização e descrever o acontecido. Notase que alguns depoimentos são mais densamente figurativizados (GREIMAS, 2004) no que se refere à caracterizações do próprio sujeito do assédio, especialmente quanto à roupa. Tais informações seriam "desnecessárias" no contexto dos relatos, o que implica (GRICE, 1975) a suposição de uma estratégia discursiva de prevenção à culpabilização da vítima. Para verificar essa hipótese, a análise apresentada neste artigo concentra-se em depoimentos sobre assédios ocorridos em Curitiba; dos 145 registros feitos na cidade entre 2014 e 2018, 21 apresentam a densidade figurativa de vestuário que manifesta a estratégia de "defesa". A relação desses depoimentos com o contrato semiótico de culpabilização da vítima pode ser de aceitação, de recusa, de despistamento (não recusa) ou de questionamento (não aceitação). Propõe-se, no entanto, que uma atitude - discursiva, é importante frisar - de enfrentamento à lógica de culpabilização da vítima talvez se deva pautar pela ignorância de tal contrato e consequente invalidação de sua lógica. $\mathrm{Na}$ imprensa, por exemplo, essa postura se manifestaria pela não divulgação da roupa usada pelas vítimas no momento em que sofreram violência.
\end{abstract}

Palavras-chave: semiótica discursiva; densidade figurativa; implicatura; violência contra a mulher; roupas.

ABSTRACT: The street sexual harassment is a type of violence against women that is difficult to face, among other factors, due to the lack of data. This lack was lessened in Brazil by the enactment of the sexual harassment law in 2018. Before it, one of the initiatives that proposed to give visibility to cases of harassment was the Chega de Fiu-Fiu map, operating from 2014 to 2019. Victims of sexual harassment or its witnesses could register an occurrence on the map, indicate its location and describe what happened. It is noted that some statements are more densely figurativized (GREIMAS, 2004) regarding to the characterization of the subject of harassment, especially her clothes. Such information would be "unnecessary" in the context of the reports, which implies (GRICE, 1975) the 
assumption of a discursive strategy to prevent the victim's blame. To verify this hypothesis, the analysis presented in this article focuses on testimonials about harassments that took place in Curitiba; among the 145 records made between 2014 and 2018, 21 of them show the figurative density of clothing that expresses the "defense" strategy. The relation of these testimonies to the semiotic contract of blaming the victim can be the acceptance, the refusal, the deception (not refusal) or the questioning (non-acceptance). It is proposed, however, that an attitude - discursive, it is important to emphasize — of facing the logic of victim's blame may be the ignorance of such a contract and the consequent invalidation of its logic. In the press, for example, this attitude would be manifested by the non-disclosure of the clothes worn by the victims at the time they suffered violence.

Keywords: discursive semiotics; figurative density; implicature; violence against women; clothes.

\section{Introdução}

O assédio sexual de rua é uma violência que afeta profundamente a vida das mulheres, ainda que distintamente a depender das intersecções de raça e etnia, classe social, orientação sexual, identidade de gênero, condições físicas e faixa etária das pessoas assediadas (ONETTO, 2019). Com a promulgação da lei brasileira de importunação sexual em 2018 , o ato passou a ser tipificado como crime (e não mais como contravenção penal) e as ocorrências começaram a ser contabilizadas pelo Governo, o que deverá, ou deveria, orientar ações de enfrentamento ao problema.

Dificilmente, porém, essa quantificação oficial oferece uma real dimensão do assédio ${ }^{2}$. Obstáculos para a coleta de dados são a vergonha de denunciar, a recusa de delegacias em registrar boletins de ocorrência e a desinformação ou resistência do Judiciário ${ }^{3}$, resultando em subnotificação e impunidade. Tais dificuldades se devem sobremaneira ao aspecto cultural da violência contra a mulher, o que pede um enfrentamento não apenas penal, mas principalmente educacional e comunicacional. Daí a necessidade de se entender melhor as discursividades e os sentidos do assédio sexual de rua.

Antes da existência de estatísticas oficiais, possíveis fontes de dados para investigações sobre o assédio foram as ferramentas e relatórios produzidos e compartilhados por iniciativas como a da ONG Think Olga, que de 2014 a 2019 manteve a plataforma Chega de FiuFiu. Ela permitia que vítimas ou testemunhas de assédio registrassem a ocorrência em um mapa, informando local, data e horário e descrevendo a situação. O conteúdo desses

1 Lei $13718 / 18$, de autoria da então senadora Vanessa Grazziotin (PCdoB/AM). A lei caracteriza como importunação sexual o ato libidinoso praticado contra alguém, e sem autorização, a fim de satisfazer desejo próprio ou de terceiro (BRASIL, 2018).

2 O crime de importunação sexual aparece no Anuário Brasileiro de Segurança Pública 2020 com dados de 2018 e 2019 (BUENO; LIMA, 2020, p. 131). Foram registradas 8.068 ocorrências de importunação sexual em 2019 no país — o que está muito longe de espelhar a realidade do problema.

3 Indício desse comportamento é a cartilha sobre importunação sexual elaborada pela ONG Think Olga para o Tribunal Regional Federal da Terceira Região, na qual se lê um apelo: "Compreendendo o fundamental papel das nossas magistradas e magistrados, nosso convite é para que se transformem em parceiras e parceiros neste processo. Garantir a justiça nas relações de gênero é garantir que o Brasil não repita erros. Precisamos avançar e suas decisões são determinantes" (THINK OLGA, 2020, p. 5). 
registros - sem a identificação de autoria - era disponibilizado em uma planilha que podia ser baixada livremente ${ }^{4}$. Em janeiro de 2018, havia 3773 registros no Brasil e 145 em Curitiba, cidade-objeto da minha pesquisa à época (BAGGIO, 2019) ${ }^{5}$. Essa delimitação geográfica será mantida na análise apresentada mais adiante.

Os dados do Chega de Fiu-Fiu, mesmo sem representatividade estatística, permitiram delinear um perfil quantitativo do assédio sexual de rua, algo praticamente inexistente até então. No entanto, mais produtivos do que os dados talvez sejam os depoimentos postados no mapa. As descrições das ocorrências possibilitam apreender aspectos da discursivização e da narrativizacão do assédio a partir da visão de seus sujeitos, e é o que se faz neste artigo.

Aqui, o foco está na análise do que parecem ser estratégias adotadas pelas enunciadoras para se resguardarem de uma possível revitimizacão: a culpabilização da própria vítima pela violência perpetrada contra ela, algo bastante frequente nos casos de violência contra a mulher (FARIA; CASTRO, 2014). Dada a recorrência histórica dessa culpabilização, é compreensível que ela apareça como premissa a partir da qual serão construídos discursos de "defesa".

Tal estratégia de defesa é percebida em depoimentos nos quais as enunciadoras discutem aspectos do contrato semiótico que rege a dinâmica do assédio, questionando a justiça ou injustiça da sanção aplicada pelo destinador-julgador (o assediador ou a sociedade). Ou seja, são relatos que descrevem não apenas o assédio e o logradouro em que ocorreu, mas que descrevem também a pessoa assediada e suas escolhas de mobilidade - elementos que, de forma alguma, poderiam justificar o assédio. Esses depoimentos são figurativizados por elementos relacionados ao momento do assédio, distribuídos em três temas principais: 1) o período do dia em que ocorreu, 2) o motivo ou os pontos de origem/destino do deslocamento que o sujeito assediado fazia e 3) o vestuário (roupas e arranjos corporais) desse sujeito. Depoimentos densamente figurativizados com os elementos desse terceiro tema são 21 dentre os 145 registrados em Curitiba, e é neles que a análise se concentra.

Os depoimentos dizem respeito ao período de 2014 a 2018 e foram coletados no âmbito de uma pesquisa de pós-doutorado (2017-2019). Apesar de a pesquisa estar concluída e de ter seus resultados já publicados, a semiotização que apresento neste artigo permanece inédita. Apesar da distância temporal que nos separa da época dos depoimentos, tais achados, infelizmente, não perdem a atualidade: o problema, mesmo com a lei, permanece ${ }^{6}$.

\footnotetext{
4 Como o mapa saiu do ar, não é mais possível ter acesso à planilha. Para consulta relacionada ao conteúdo deste artigo, disponibilizo em repositório próprio a versão baixada em 2018 e que serviu de base para esta pesquisa: https://www.researchgate.net/publication/349766930_Planilha_com_depoimentos_sobre_assedio_sexual_de_rua_ postados_na_plataforma_Chega_de_Fiu-Fiu_relativos_a_Curitiba_2014_a_janeiro_de_2018.

5 Essa referência descreve o mapa e mostra algumas de suas telas, para se possa entender como funcionava.

6 A lei, se bem aplicada e seguida, minoraria a impunidade em casos mais graves de assédio. No entanto, casos "mais leves", mas nem por isso menos prejudiciais - cantadas, olhares, xingamentos, abordagens não solicitadas dificilmente podem ser coibidos pelo aparato jurídico (BAGGIO; LUZ, 2019a).
} 


\section{Densidade figurativa nos depoimentos de assédio: implicatura e efeitos de sentido}

Algo que chama a atenção nos depoimentos é a diferença de densidade figurativa entre eles. Alguns apenas indicam o local do assédio e descrevem objetivamente o que aconteceu. Por exemplo:

Na rua martim afonso, foi seguida por 5 adolescentes entre 14 e 18 anos, dizendo que eu era mais uma que eles queriam estuprar. \#304

Já outros são mais contextualizados e apresentam elementos que extrapolariam a função explícita do mapa Chega de Fiu-Fiu, pois não seriam necessários para a caracterização do assédio. Vejamos:

Voltando ao trabalho após o horário do almoço, atravessei a Praça Tiradentes. Um homem passou do meu lado e disse: "Que delícia, se pudesse te comia toda”. \#271 (grifos nossos)

Eu estava caminhando com a minha mãe por volta das 18:00 horas. [...]. \#2028 (grifos nossos)

[...] Eu, de vestido normal, sentindo - como TODA mulher sente quando um homem olha com segundas intenções - que aquele senhor vinha me encarando durante todo o trajeto até o centro. [...] \#1431 (grifos nossos)

Esses três depoimentos, além de contarem uma história e de argumentarem sobre as condições do assédio, apresentam figuras (as partes grifadas) que tornam o texto mais figurativamente denso, especialmente quanto à caracterização da vítima do assédio.

Algirdas Julien Greimas (2004) propôs o conceito de densidade figurativa para tratar da relação entre textos da semiótica natural e textos da semiótica visual, no âmbito da diferenciação entre semiótica figurativa e semiótica plástica. Por exemplo: o retrato de uma pessoa (semiótica visual) pode ser constituído pelo olhar do observador como um signo-objeto pouco ou muito parecido com a pessoa (semiótica natural) retratada. "Muito parecido" é uma interpretação à qual se chega devido à presença de grande quantidade de feixes de traços visuais (significantes) apresentados pelo retrato que, para o observador, significam a representação da pessoa retratada. Quanto mais fácil o reconhecimento de um elemento da semiótica natural na semiótica visual, maior a densidade figurativa desta. Quanto mais difícil, menor a densidade figurativa. No primeiro caso, tem-se a iconização. No segundo, a abstração.

Greimas (2004, p. 81) entende a iconização como um "[...] desejo de fazerparecido - de fazer-crer [...]". Penso que, nos depoimentos com a presença de muitos traços descritivos significantes, estes traços operam da mesma maneira, ainda que o par de semióticas seja outro: o acontecimento assédio (semiótica natural) e o relato do

$7 \quad$ Os depoimentos foram reproduzidos conforme o registro na planilha; o número antecedido por \# se refere ao código do depoimento na planilha com os dados do mapa; estou adotando a formatação de citação longa para todos os depoimentos, mesmo que tenham menos de 3 linhas, no intuito de facilitar sua leitura e análise. 
assédio (semiótica verbal) ${ }^{8}$. Os efeitos dessa operação de adensamento figurativo ficam mais claros a partir da definição de Diana Luz Pessoa de Barros (2010, p. 81), para quem a iconização "é o investimento figurativo exaustivo da última fase do procedimento de figurativização, com o objetivo de produzir ilusão referencial ou realidade" (grifos nossos).

A escolha do sujeito da enunciação em adensar o enunciado com traços que detalham o período do dia, o motivo do deslocamento, a roupa usada no momento do assédio (e também os gestos, as palavras, as sensações e os sentimentos), sugere a intenção de retomando as palavras de Greimas e de Barros - fazer o relato o mais parecido possível com o acontecimento. Em suma, sugere um querer fazer-crer que o assédio aconteceu, que o assédio é uma realidade.

No conjunto dos depoimentos do mapa Chega de Fiu Fiu, a densidade figurativa e seu efeito de verdade têm a importante função de mostrar a existência do assédio e de caracterizá-lo como violência - e não como uma simples "cantada", como um inofensivo traço cultural da masculinidade brasileira. Porém, os depoimentos com maior iconização sugerem a busca disso e também de algo mais: além de almejar credibilidade e, eventualmente, solidariedade, o sujeito-enunciador parece querer se defender antecipadamente de uma culpabilização que já espera receber.

Essa hipótese encontra algum respaldo nas considerações sobre as práticas conversacionais. Considero os depoimentos como conversas entre os atores que revestem as duas instâncias da enunciação - a pessoa que escreveu o depoimento (no papel de sujeitoenunciador) e a sociedade leitora desses depoimentos (no papel de sujeito-enunciatário).

As práticas conversacionais, para serem bem-sucedidas, requerem certas tomadas de decisão por parte do sujeito-enunciatário quanto à chave interpretativa mais adequada para a produção de sentido do que lhe foi dito. Quando o significado mais “provável” de um texto parece não ser o mais adequado, o enunciatário faz inferências sobre as intenções do enunciador em relação ao significado desse texto. Tal fenômeno, chamado de implicatura pelo filósofo Paul Grice (1975 citado por CHIERCHIA, 2003, p. 249), consiste em um esforço de fazer interpretativo que depende não apenas da imanência do enunciado, mas também da cooperação conversacional entre os sujeitos da enunciação, cooperação essa baseada no princípio da economia ou do mínimo esforço.

Na sua manifestação linguística, essa cooperação conversacional "econômica" articula-se numa série de quatro normas, sendo uma delas relacionada à dimensão da quantidade: "não dar informação demais, nem de menos" (GRICE, 1975 citado por CHIERCHIA, 2003, p. 249) ${ }^{10}$. Diante de informações como aquelas destacadas nos depoimentos, o princípio da economia sugere ao enunciatário que esse tipo de informação deve ter um significado além daquele explícito; caso contrário, seria excessiva, desnecessária, e não atenderia à cooperação conversacional. $\mathrm{O}$ enunciatário vai então buscar a chave

8 Coloco em suspensão, nas análises, o sincretismo semiótico dos textos verbais, que também produzem sentido por meio das características visuais das letras, da distribuição das manchas de texto etc.

9 GRICE, Paul. Logic and conversations. In: COLE, P.; MORGAN, J. (org.). Syntax and semantics 3: speech acts. New York: Academic Press, 1975.

10 As outras normas são a relação (seja relevante), a qualidade (restrinja-se ao que você tem evidências de que é verdade) e o modo (seja claro e organizado; evite obscuridades e ambiguidades). 
interpretativa fora do enunciado. Vejamos um exemplo: no caso do depoimento em que, para descrever o assédio, o enunciador explica que estava "voltando ao trabalho" e que isso se dava "após o almoço" (portanto, à luz do dia), uma inferência possível é que essa aparentemente supérflua caracterização de motivo de deslocamento e de período do dia quer indicar bom comportamento, atendimento às prescrições da circulação feminina no espaço urbano.

O sentido que atribuo a essa inferência é também ele uma inferência, justificada pelas pistas deixadas pelo sujeito-enunciador no enunciado - pistas que remetem ao contexto socio-histórico e às relações intertextuais (BARROS, 2010). Se, como nos dizem os princípios da semântica fundamental (GREIMAS; COURTÉS, 2008, p. 402-403), o elemento presente de um par de significação convoca seu oposto, mesmo que ausente, dizer "voltando ao trabalho após o almoço" — motivo e horário que ocupam uma posição eufórica na axiologia das características dos deslocamentos franqueados às mulheres — produz sentido também pela inferência dos elementos que não foram ditos, e que ocupam o polo oposto e disfórico das respectivas axiologias. Esses elementos poderiam ser "andando à toa"/"indo para a balada" em oposição a "voltando ao trabalho", e "à noite"/"de madrugada" em oposição a "após o almoço"; são elementos que o mencionado contexto socio-histórico e os discursos prescritivos sobre o comportamento feminino consideram inadequados ${ }^{11}$.

Em resumo, ao escolher iniciar seu depoimento com "voltando ao trabalho após o almoço", o sujeito-enunciador também diz: "eu não estava à toa, eu me comportei bem, eu não merecia ser assediada". Obviamente, essa defesa prévia sugere que há o reconhecimento de um contrato regido pela lógica de culpabilização da vítima, pois caracterizar a vítima e suas escolha implica dizer que esses fatores podem ter a ver com o assédio.

\section{O contrato da culpabilização da vítima}

Nos exemplos de depoimentos, como vimos, as figuras que sugerem a intenção de defesa prévia se referem ao motivo do deslocamento, ao período do dia, à companhia durante esse deslocamento e à roupa usada no momento do assédio. Para cada uma dessas figuras, consideradas eufóricas na axiologia dos comportamentos das mulheres, existe a presençaausente da contraparte disfórica, conforme exemplificado em relação ao depoimento \#271.

O apelo a essas figuras não significa, necessariamente, que o sujeito-enunciador, nas suas práticas de vida, esteja de acordo com a axiologia de valores em que estes se distribuem. No entanto, por estarem presentes no enunciado, essas figuras indicam que o sujeito reconhece e opera a axiologia na sua estratégia argumentativa. De uma forma mais geral, as figuras e os comportamentos, bem como os valores por eles revestidos, compõem dois tipos de papéis temáticos femininos que o contexto socio-histórico comumente entende como o da "decente" (posição eufórica) e o da "vadia" (posição disfórica).

Considerando o percurso narrativo dos depoimentos, há algo geral para todos eles: o destinador (não apenas o assediador, mas todos os atores pessoais ou institucionais que

11 Para uma discussão sobre a interdição da mulher ao espaço público, as relações entre o ato de caminhar e o controle da sexualidade feminina, ver A história do caminhar, de Rebecca Solnit (2016), especialmente o capítulo "Caminhadas depois da meia-noite: mulheres, sexo e espaço público". 
culpabilizam a vítima de violência) propõe um contrato por meio da intimidação. Esse contrato reza que mulheres devem ser "decentes"; caso contrário, sofrem assédio. E na medida em que os depoimentos, como vimos, constroem-se pela oposição dos valores de decência e de licenciosidade, nota-se que o contrato é aceito: o próprio contrato é utilizado na argumentação de defesa prévia (“viram como eu estava decente?"). Portanto, quando ocorre a sanção negativa — o assédio —, os sujeitos se perguntam: por que minha performance foi punida, se eu cumpri o contrato?

O problema está no efeito de veridicção desse contrato, tido como verdadeiro pelas destinatárias. No entanto, a realidade não é assim. Casos de violência e de assédio ocorrem com "qualquer tipo" de mulher, seja ela "decente" ou "vadia"; portanto, assumir o papel temático eufórico não consiste em uma garantia de proteção contra essa violência. A tipologia em si — que também é um contrato - é igualmente falaciosa, pois, na prática, mesmo mulheres "decentes" não escapam de ser classificadas como "vadias". Em suma, o destinador-manipulador propõe algo que parece, mas não é - ou seja, uma mentira. E por que o destinatário crê? Talvez porque seja uma mentira que se ouve desde sempre, na diacronia do mundo e na de cada uma de nós.

Se o reconhecimento do contrato é algo comum aos depoimentos selecionados para análise, o ponto em que eles divergem é quanto ao tipo de relação que estabelecem com esse contrato e quanto ao fazer interpretativo a respeito da sanção negativa recebida. Para fazer essa discussão, detenho-me agora especificamente nos depoimentos que apresentam a descrição das roupas, pois é a roupa que a mulher usa um dos motivos mais frequentes para justificar a violência cometida contra ela ${ }^{12}$.

\section{A figurativização do vestuário e os diálogos estabelecidos entre os depoimentos e o contrato de culpabilização da vítima}

No mapa Chega de Fiu Fiu, dos 145 depoimentos relativos a Curitiba, 33 contêm figuras de vestuário e de configuração corporal. O vestuário do assediador é mencionado em 14 depoimentos, o vestuário da pessoa assediada é mencionado em 21 (um dos depoimentos menciona o vestuário de ambos).

Há diferença no objetivo de informar o vestuário de um e de outro, a exemplo do que se vê no depoimento \#1431, já parcialmente apresentado:

\footnotetext{
Havia único homem de mais ou menos 60 anos e uniforme de cobrador/motorista, sentado em um dos assentos individuais dentro de um ônibus cheio de mulheres.

Eu, de vestido normal, sentindo - como TODA mulher sente quando um homem olha com segundas intenções - que aquele senhor vinha me encarando durante todo o trajeto até o centro. [...]
}

12 Essa discursividade é tão disseminada que acabou pautando uma exposição de roupas que mulheres (e meninas) usavam quando foram estupradas (EXPOSIÇÃO, 2018). A diversidade de peças expostas confirma o óbvio: não há roupa que proteja a mulher da violência, pois não é essa a sua causa. 
Ele tentando se esfregar em mim, estava prestes a passar a mão no meu corpo. Segurei a mão do velho, ele soltou com força, a porta do ônibus se abriu. [...] 30 minutos depois meu pai veio me encontrar. Fomos para a delegacia.

Depois de aguardar uma hora para sermos atendidos, o resultado (já esperado) foi: $[\ldots]$

“minha filha, não use vestidos, saias ou shorts no transporte coletivo. Você

incentiva os homens a agirem contra você”.

A Segurança Pública é uma instituição FALIDA.

Nós mulheres temos que nos unir em todos esses casos.

[...] Não suportamos mais não termos o DIREITO CONSTITUCIONAL de caminhar com liberdade e tranquilidade em qualquer rua da cidade ou no transporte público. \#1431 (grifos nossos)

A descrição da roupa e da configuração corporal do assediador parece almejar uma identificação do agressor. Essa identificação serve a dois propósitos: 1) fazer com que o agressor seja reconhecido por outras mulheres e, eventualmente, pela polícia; 2) identificar o seu papel temático e a sua atorialização. Muitos assediadores vestem uniformes que indicam sua profissão, local de trabalho ou estudo. No caso do depoimento \#1431, o sujeito é um funcionário do sistema de transporte público de Curitiba ${ }^{13}$. Outros sujeitos com esse mesmo tipo de trabalho aparecem em outros depoimentos, o que por si só deveria fazer o poder público se manifestar de maneira mais efetiva em relação ao assédio.

Já a descrição da roupa do sujeito assediado — “eu, de vestido normal” — tem a função, conforme venho propondo ao longo do trabalho, de apresentar uma defesa prévia. Esse depoimento \#1431 também exemplifica o contrato a partir de cuja lógica a defesa se constrói. Na última parte do depoimento, o sujeito-enunciador reproduz a fala de um policial que culpabiliza a vítima pela violência: o fato de usar roupas que figurativizam o papel temático da "vadia" ("vestidos, saias ou shorts") teria sido a causa do assédio. O discurso do policial — representante de um forte destinador, que é o Estado — não responsabiliza o assediador, e sim o sujeito assediado.

Para esses dois sujeitos — policial e mulher assediada — o contrato apresenta uma pequena variação quanto à figurativização da "vadia". A mulher entende que o vestido, desde que "normal”, não faz parte deste papel; já o policial não faz a distinção, e inclui a peça em si no rol da caracterização disfórica ${ }^{14}$.

13 O sistema de transporte (ônibus, terminais, paradas, estações-tubo) é o equipamento público com maior número de ocorrências de assédio em Curitiba, segundo dados da Guarda Municipal (BAGGIO, 2020).

14 Não há uma absoluta estabilidade de sentidos das roupas na axiologia proposta por esse contrato. A valoração de cada uma depende da relação estabelecida com outras explicitamente mencionadas no enunciado ou convocadas como complemento da oposição semântica proposta. O shorts e o vestido podem assumir posições eufóricas ou disfóricas a depender das figuras de expressão que apresentam, ou das outras peças de vestuário com as quais se relacionam. Mesmo a calça, frequentemente arrolada entre as peças "decentes", pode ir para o outro campo semântico se for justa. Este trabalho não aprofunda o inventário de peças de roupa, mas essa observação a respeito da instabilidade de sentidos é produtiva para se discutir a questão da falsidade do contrato. Afinal, nos depoimentos, as roupas mudam de valoração, mas todas elas estiveram presentes em casos de assédio. 
O final do depoimento mostra claramente que sua autora considera revoltante tanto a atitude dos homens que assediam quanto a postura da segurança pública, que não pune os agressores e culpabiliza a vítima. No entanto, a passagem com a descrição da roupa — "Eu, de vestido normal" - sinaliza um certo tipo de diálogo com o contrato. Não é exatamente o contrato que é considerado injusto, mas sim a aplicação da sanção negativa — o assédio - pelo destinador. Afinal, se a roupa era "normal", o contrato da decência estaria sendo cumprido. Então, qual o motivo da sanção? Esse depoimento ilustra um dos tipos de diálogo com o contrato: o da aceitação.

\subsection{Os tipos de diálogo}

Vários outros relatos sugerem essa aceitação do contrato. No \#1431 havia também a adoção de uma postura contrária à situação, mas em outros existe apenas a expressão de uma sensação de injustiça: a sanção negativa (o assédio) não deveria ter acontecido, pois os sujeitos seguiram o contrato que acreditam ser verdadeiro. Alguns exemplos:

Era inverno, eu estava saindo da faculdade pro estágio muito, muito atrasada. [...] \#1982 (grifos nossos)

Um dia estava voltando do trabalho e vinha caminhando do ponto de ônibus até a minha casa, quando no meio do caminho, um homem começo a falar: oh gostosa, nossa que delicia, se eu te pego te chupo inteira. Depois: uma hora eu te pego, que bunda boa. Me senti um lixo, me senti vulgar e fiquei ate com medo que ele me seguisse até em casa, mesmo ele tendo desviado para outro caminho. Me senti a pior das mulheres, como se eu tivesse com uma roupa apelativa, quando no caso eu estava com uma calça jeans, tenis e uma blusa de manga longa larguinha e uma jaqueta. \#540 (grifos nossos)

Estava voltando para casa, com um vestido que não era curto nem colado. [...] \#1624 (grifos nossos)

Estava indo a academia, vestia moletom largo, não gostava do meu corpo. Eu não estava maquiada, e nem ao menos tinha seios volumosos. Meu cabelo estava preso. Eu estava muito feia, em uma roupa larga, isso mostra que roupa não é motivo. \#1368 (grifos nossos)

Para argumentar sobre a injustiça da sanção, os sujeitos apelam para a figurativização da decência de sua aparência corporal. Nesses depoimentos, tais figuras são:

1. a menção à estação do ano ("era inverno") — ou seja, por ser uma época de frio em Curitiba, o corpo estava todo coberto com roupas que poderiam até deformá-lo, como no caso do "moletom largo" e "roupa larga" do depoimento $\# 1368$;

2. a caracterização de um certo conjunto de peças ditas "não apelativas" — calça jeans, tênis, blusa de manga longa larguinha e uma jaqueta; um vestido que atendia à prescrição por não ser nem curto, nem colado; 
3. a caracterização de certas configurações corporais - usar maquiagem, cabelos soltos, ser bonita ou ter seios volumosos justificaria o assédio, pois compõem o papel temático disfórico.

Esse inventário da aparência decente apresenta tanto figuras de conteúdo — as peças de roupa - como figuras de expressão: largo, longo, não curto, não colado, não volumoso, contido. $\mathrm{O}$ vestido assume uma posição ambígua na axiologia de valor da decência. Mesmo quando ausente dos depoimentos, pelos procedimentos de oposição semântica ele representa a figura da "vadia" nas ocasiões em que a calça é convocada para figurativizar a decência. Quando ele está presente no depoimento, a axiologia vadia $\mathrm{x}$ decente é homologada por aspectos eidéticos do vestido: curto $\mathrm{x}$ comprido, justo $\mathrm{x}$ folgado, discreto $\mathrm{x}$ decotado. Esse primeiro grupo de depoimentos, portanto, questiona a justiça da sanção, mas não a do contrato, que é aceito: "eu estava decente, não merecia o assédio".

O grupo seguinte reúne depoimentos que, por sua vez, questionam a justiça do próprio contrato. Por exemplo:

De manhã ia colocar um vestido porque está um calor de rachar. Não, vou por shorts. Eu ponderei sobre minha roupa porque ia sair de casa. Homens em carros olhando, motociclistas, mostrei o dedo e continuei meu caminho. Meninas, o depósito do Mercadorama tá cheio de caminhoneiro machista. "ô laia", "falou comigo?" "queria que tivesse mexido com você?" "não né, mulher não é objeto" Não deixem passar \#respeitaasminas \#3430 (grifos nossos)

O sujeito tem consciência do contrato, mas não o aceita sem questionamento. Outra consciência interessante é em relação ao repertório de figuras que constituem um ou outro papel temático: aqui, a oposição se dá entre o vestido (vadia) e o shorts (decente). Note-se, no entanto, que apesar de desvelar a injustiça desse contrato, o sujeito não deixa de convocar a lógica da culpabilização para "defender" suas escolhas. Ela iria colocar um vestido "porque está um calor de rachar". A escolha dessa justificativa para se usar vestido sugere que, se o dia não estivesse assim tão quente, a escolha dessa peça (apesar de não ter sido levada adiante) poderia indicar a manifestação do papel temático disfórico, aquele que motiva o assédio.

Depoimentos desse tipo caracterizam-se por uma não aceitação, que podemos parafrasear como: "roupas causam assédio, mas acho um absurdo". Esse segundo grupo, portanto, estabelece uma relação de contraditoriedade com o primeiro.

O terceiro grupo apresenta depoimentos que, em relação de oposição com o primeiro (o da aceitação), recusam o contrato. Um exemplo:

Resolvi correr um pouco pelo bairro e ao passar por essa rua, que aparentemente não tinha ninguém, senti uma mão na minha bunda. O susto foi tão grande que dei um coice para trás e acertei a pessoa. Só vi que era um homem com moletome capuz na cabeça de cor escura, ele tentou segurar meu pulso, enquanto eu puxava com força para me livrar dele, ele me xingava de puta e vadia, saí correndo muito rápido. Até me perdi no trajeto, sem prestar atenção por onde ia. Liguei para o meu namorado contando o que tinha acontecido, ele foi me encontrar e tentamos procurar o homem, mas não vimos mais ninguém. Provavelmente ele saiu de 
algum mato que fica por lá. Duro foi ouvir de outros que a culpa era minha, porque estava correndo com shorts curto e sozinha. [...] \#1977 (grifos nossos)

Existem alguns "argumentos de defesa" nesse depoimento (apesar de estar correndo sozinha, ela tem namorado), mas a roupa não é um deles. A roupa é mencionada pelo sujeito não em discurso direto, mas em discurso indireto, ou seja, é a reprodução da fala de outros. Não é a mulher quem aceita o contrato, mas os outros, ao culpabilizarem-na. $\mathrm{O}$ sujeito tem consciência desse procedimento e o considera ainda eventualmente pior do que o próprio assédio (“duro foi ouvir de outros [...]"). Em relação à roupa mencionada, o shorts, surge novamente a figura de expressão como constituinte do papel temático disfórico: ele é curto. Uma paráfrase do diálogo desse tipo de depoimento com o contrato seria: "a culpa pelo assédio não é minha".

Dessa postura de recusa do contrato deriva a última posição, a ele contraditória, de não recusa. Os depoimentos desse grupo caracterizam-se pela consciência do contrato e pelo seu não questionamento, mas também pela não submissão automática a ele. Por exemplo:

Sempre que necessito pegar ônibus passo muito medo, pois os assédios sempre ocorrem, seja ele só pelo olhar ou verbal. Apenas saio de casa com vestido ou decote quando não vou andar uma longo caminho a pé ou estou de carro. \#1468 (grifos nossos)

Era um dia muito quente e eu estava voltando para casa no final da tarde. Foi quando um menino (mais ou menos 23 anos) passou muito rápido de bicicleta do meu lado, ele colocou a mão em da minha saia, pela frente, agressivamente, e continuou seu caminho. Eu gritei "filho da puta". [...] Eu cheguei chorando em casa e minha mãe riu, disse que essas coisas acontecem e que eu tenho que parar de usar vestido. Meu pai não esboçou nenhuma reação. Eu chorei mais e sempre que uso esse vestido sinto medo de sair na rua. \#2805 (grifos nossos)

O sujeito do primeiro depoimento conhece o contrato e os repertórios figurativos dos papéis temáticos geridos, mas adota estratégias para evitar a sanção quando decide não cumprir contrato. Dentre as figuras do repertório disfórico estão o vestido (de conteúdo) e o decote (de expressão). Essas roupas são adotadas apenas em algumas circunstâncias, mas não deixam de ser adotadas.

No segundo depoimento, assim como em outros desse grupo, o sujeito justifica o uso da peça disfórica, a saia (ou vestido), por meio da alusão ao clima. As pessoas com quem conversa sobre o assédio recomendam a submissão ao contrato ou se omitem em relação a ele. $\mathrm{O}$ sujeito, portanto, tem consciência do contrato, aceita-o, mas ainda assim o enfrenta de alguma forma. Mesmo com medo, não deixa de usar o vestido ("sempre que uso esse vestido"). Em resumo, a postura do sujeito nesse tipo de diálogo com o contrato é: "roupas causam assédio, mas uso mesmo assim". 


\subsection{Contrato de culpabilização: aceitar, despistar, recusar, questionar - ou ignorar?}

A distribuição desses tipos de diálogo com o contrato na representação visual do quadrado semiótico (figura 1) seria, portanto, a da oposição entre aceitação e recusa do contrato. Do primeiro termo deriva a postura de não aceitação, ou seja, a de questionamento do contrato. Do segundo, por sua vez, deriva a não recusa, ou seja, o despistamento ou enfrentamento do contrato.

Figura 1 - representação visual dos tipos de diálogo entre os depoimentos do mapa

Chega de Fiu-Fiu e o contrato de culpabilização da vítima de assédio a partir da roupa

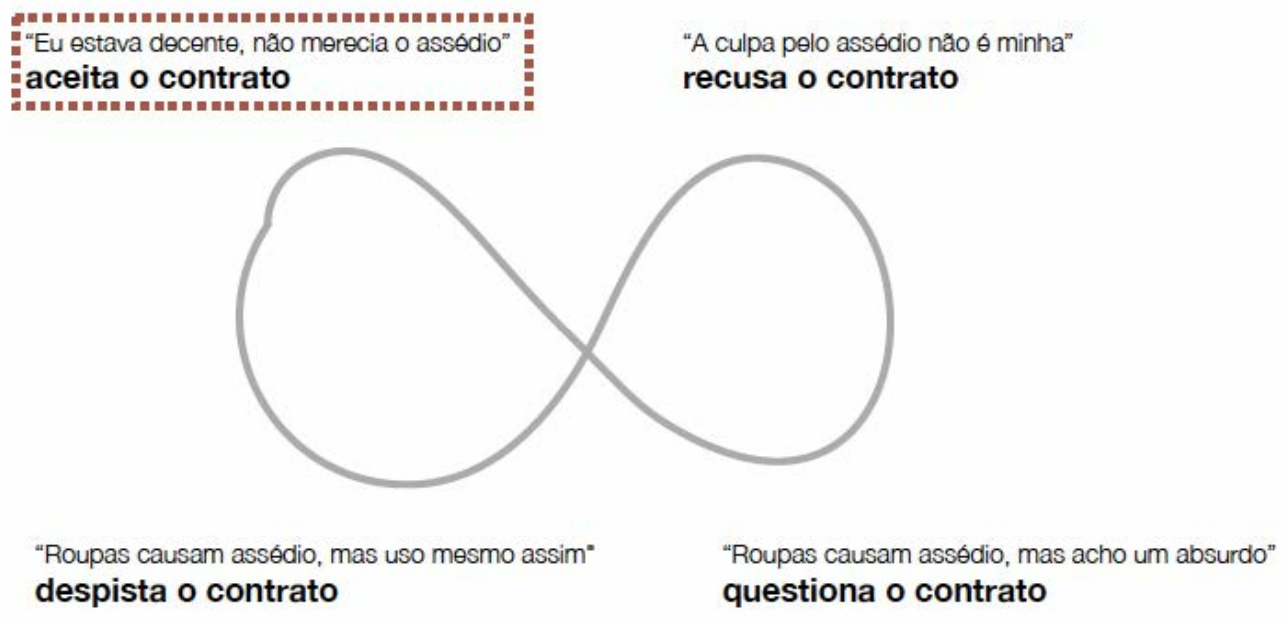

Fonte: a autora com base nos depoimentos do mapa Chega de Fiu-Fiu.

O percurso sugerido pela forma elíptica de articulação entre os quatro tipos de diálogo pretende dar conta da possibilidade de mudança na tomada de posição em relação ao contrato, de acordo com as experiências de assédio vividas pelo sujeito e, também, pela eventual e progressiva tomada de consciência sobre a lógica mais geral na qual se baseia o contrato. A própria tipologia dos depoimentos é uma amostra desse processo, pois ela revela distintas posturas de mulheres em relação ao assédio - ainda que todas tenham se disposto a utilizar uma ferramenta (o mapa Chega de Fiu-Fiu) que, por si só, já indica uma atitude mais geral de enfrentamento.

Curiosamente, uma das possibilidades desse percurso pode ser percebida na organização narrativa de um dos depoimentos do corpus. Este relato mostra a transição da aceitação do contrato para o seu questionamento e depois para a sua recusa:

\footnotetext{
Estava chegando ao meu local de trabalho, usando um vestido florido acima do joelho e meia calça preta por baixo [aceitação do contrato]. Um sujeito passou por mim e disse "ô que delícia hein?!" e mais algumas coisas que não ouvi muito bem, mas imagino que tenham sido do mesmo nível. Isso ocorreu já dentro do prédio, nos corredores que separam as salas comerciais. Mesmo que eu não usasse a meia calça por baixo, este infeliz não tinha o menor direito de me constranger na frente das pessoas e falar comigo como se eu fosse um pedaço de carne pronto a ser devorado. [questiona o contrato] Senti muito ódio e cheguei a pensar que não
} 
deveria mais usar vestidos, mas mudei de ideia, porque EU MANDO NA MINHA $L I B E R D A D E$ [recusa o contrato] e esse homem nojento e sem o mínimo de respeito não pode e nem vai decidir isso por mim! \#1977 (grifos nossos)

É importante deixar muito claro que as tipologias apresentadas — que articulam gradações de aceitação ou recusa do contrato - referem-se a discursos, e não a práticas. Os depoimentos não correspondem à "realidade" das posturas adotadas pelos sujeitos em relação ao assédio. A iconicidade dos depoimentos está associada a um acontecimento específico, a um fazer-crer no assédio e na não culpabilidade do sujeito. Essa iconicidade não tem a ver com uma correspondência absoluta entre as posturas apresentadas nos depoimentos e as efetivas decisões de conduta assumidas pelos sujeitos em seus deslocamentos pela cidade. Em resumo: um depoimento que manifesta um discurso de aceitação do contrato não indica, de forma alguma, que o sujeito ache "correto", "aceitável", "compreensível" o assédio sexual de rua, seja lá qual for a justificativa que se dê para o exercício desse assédio (a roupa, o local, o horário, a companhia etc.).

Discursivamente, todas as tipologias - mesmo a da recusa - reconhecem de alguma forma o contrato e sua gerência sobre a vida das mulheres, pois seus depoimentos apresentam não apenas uma caracterização do assédio, mas também da vítima. Um discurso que efetivamente quebrasse essa lógica seria, portanto, não o de recusar o contrato, e sim o de ignorá-lo. Novamente, não se trata de uma prática - pois, na vida real, ignorar o contrato pode representar um risco à segurança —, mas de efeitos de sentido discursivos.

Ignorar o contrato é, por exemplo, não mencionar a roupa (e outras caracterizações da vítima) ou mencioná-la apenas se a roupa mesma for um sujeito participante do ato. É o que se vê neste depoimento do corpus:

Caminhando pelo centro da cidade a caminho do prédio onde eu moro, um homem me abordou colocando a mão em baixo do meu vestido apertando as minhas partes intimas. As únicas testemunhas foram outros dois homens que riram de mim. \#2457

A menção ao vestido é necessária para descrever o ato de assédio cometido, mas ela não está a serviço da caracterização da mulher ou da defesa sobre sua decência (ainda que a menção ao destino do deslocamento seja uma marca de defesa). Por não haver defesa prévia, não há diálogo com o contrato de culpabilização da vítima em relação à roupa. $\mathrm{O}$ contrato, ao menos nessa modalidade, não é recusado: ele é ignorado.

De forma geral, os depoimentos mais "abstratos" - a exemplo do depoimento \#304, apresentado no início da segunda seção deste trabalho - , com pouca densidade figurativa de elementos que caracterizam a vítima ou suas escolhas, sugerem a ignorância do contrato. O sujeito não sente necessidade de se explicar ou de provar a própria inocência por meio da menção à roupa porque não vê em sua atitude/vestuário uma culpa da qual precise se defender.

A ignorância do contrato, que aqui é uma constatação a partir de enunciados já enunciados, pode ser uma orientação para a elaboração de narrativas sobre assédio e sobre a violência contra a mulher. 
Por exemplo: é relevante, no jornalismo, informar o local onde um crime sexual aconteceu (até porque a maior parte deles ocorre dentro de casa, cometidos por parentes, e não nas ruas, cometidos por estranhos), mas não é relevante mencionar a roupa que a vítima usava no momento do crime e nem as suas características corporais. E, no entanto, a imprensa insiste em fazer isso ${ }^{15}$.

Voltando à implicatura de Paul Grice, qual o motivo para a presença, na notícia, dessa informação "a mais", desnecessária para o relato do fato, e que, portanto, desrespeita o princípio da economia na cooperação conversacional? Só se pode pensar na reiteração, ainda que não intencional, do discurso que coloca na mulher e em seu vestuário a responsabilidade por evitar a violência cometida conta ela.

Considerando a importância do destinador imprensa, a maior presença, nas notícias, de um contradiscurso que ignore o contrato de culpabilização da vítima pode contribuir para a mudança cultural sem a qual não se pode diminuir ou enfrentar assertivamente esse tipo de violência.

\section{Considerações finais}

Nas diversas etapas da pesquisa sobre assédio sexual de rua que desenvolvi nos últimos anos (de 2015 a 2019), destaquei a importância dos aplicativos de mapeamento de assédio - a exemplo do mapa Chega de Fiu-Fiu — para a visibilização dessa prática e para a constatação de seu caráter social e coletivo, e não particular e individual (BAGGIO; LUZ, 2019b). Na medida em que praticamente não havia estatísticas oficiais sobre os casos de assédio (e elas permanecem insuficientes), a discursividade manifestada pelos aplicativos - seja nas suas interfaces, seja nos dados neles registrados - funcionava como ponto de partida, ainda que limitado, para aqueles que desejassem uma melhor compreensão do problema. E os relatos do Chega de Fiu-Fiu são um dos exemplos mais produtivos dessa manifestação discursiva.

Algo que se pode compreender a partir dos depoimentos é que, mesmo tendo sido registrados em uma plataforma de enfrentamento ao problema, alguns não conseguem escapar da lógica do contrato que rege o assédio. Essa apreensão quanto à permanência do contrato - que não apenas é injusto como também mentiroso na sua lógica interna - é importante porque aponta caminhos para o tratamento discursivo do assédio. Como sugeri antes, "ignorar" o contrato poderia ser uma postura ativa adotada pela imprensa e por outras instâncias enunciativas para destinar entendimentos que não culpabilizem a mulher pela violência recebida.

Vale ressaltar ainda um aspecto quanto à sanção negativa operada no programa da decência, da qual o sujeito assediado reclama (com razão, pois ele estava decente) nos

15 Juliana de Faria e Bárbara Castro comentam o papel da imprensa na reiteração do contrato de classificação das mulheres em "decentes" e "vadias" e da relação entre violência e comportamento da mulher — ainda que os fatos, registrados por essa mesma imprensa, revelem a falsidade do contrato. Para as autoras, "A imprensa poderia ser vista como um espaço público capaz de traduzir a violência contra a mulher de forma clara e acessível. Mas, frequentemente, reproduz o discurso de desimportância e restrição à vida doméstica. Tal mentalidade arcaica pode aparecer em sutilezas como revelar a roupa que uma sobrevivente de estupro vestia ou até mesmo na culpabilização escancarada da vítima - como 'dicas' para evitar o abuso sexual do tipo 'não saia de casa desacompanhada' ou "não beba muito"' (FARIA; CASTRO, 2014, p. 44-45). 
depoimentos do tipo "aceitação do contrato". A sanção não é a expressão de uma vingança contra a mulher que descumpriu as prescrições de circulação no espaço público, pois a vingança, como nos lembra Barros (2010), indica a ação de um destinador individual. Tratase mais exatamente de uma punição, atitude operada por um destinador social. Portanto, o combate ao assédio exige a tomada de várias providências, algumas de ordem penal, mas muitas outras de ordem comunicacional e educativa.

Encaixam-se nessas duas últimas o cuidado com a elaboração das mensagens noticiosas e publicitárias e, principalmente, a inclusão da educação sexual e de gênero nas escolas. Isso requer que se tome consciência quanto ao estatuto social do destinadormanipulador e do destinador-julgador do percurso narrativo do assédio. $\mathrm{O}$ assediador pode até ser atorializado por um sujeito individual, mas os valores, o julgamento e a sanção são destinações socioculturais.

\section{Referências}

BAGgIO, Adriana Tulio. Perfil do assédio sexual de rua em Curitiba segundo o mapa colaborativo "Chega de Fiu-Fiu". In: CONGRESO DE LA ASOCIACIÓN LATINO AMERICANA DE INVESTIGADORES DE LA COMUNICACIÓN, 14., 2018, San Jose. Memorias. Grupo Temático 15 - Comunicación y Ciudad. San Jose: Universidad de Costa Rica; Alaic, 2019. Disponível em: http://alaic2018.ucr.ac.cr/sites/default/files/2020-01/ GT\%2015\%20-\%20ALAIC\%202018_0.pdf. Acesso em: 20 fev. 2021.

BAGGIO, Adriana Tulio; LUZ, Nanci Stancki da. A impunidade do assédio sexual de rua: um vácuo jurídico sustentado pela cultura da violência contra a mulher. In: Bertotti. B. M. et al. Gênero e resistência: memórias do II Encontro de Pesquisa Por/de/sobre Mulheres. Vol. 2. Porto Alegre: Editora Fi, 2019a. p. 331-352. Disponível em: https://3c290742-53df4d6f-b12f-6b135a606bc7.filesusr.com/ugd/48d206_c47ad1d091cb489a895a1de77c2619d9. pdf. Acesso em: 20 fev. 2021.

BAGGIO, Adriana Tulio; LUZ, Nanci Stancki da. A dimensão política do assédio sexual de rua: aplicativos de mapeamento como iniciativas de cidade inteligente. Estudos Semióticos, v. 15, n. 1, p. 132-151, 2019b. Disponível em: http://www.revistas.usp. br/esse/article/view/160193. Acesso em: 20 fev. 2021.

BAGGIO, Adriana Tulio. Ônibus livres do fiu-fiu. O Expresso, Curitiba, 15 dez. 2020. Disponível em: https://oexpresso.curitiba.br/2020/12/15/onibus-livres-do-fiu-fiu/. Acesso em: 19 fev. 2021.

BARROS, Diana Luz Pessoa de. Teoria semiótica do texto. 4. ed. São Paulo: Ática, 2010.

BRASIL. Lei n⿳ 13.718, de 24 de setembro de 2018. Brasília: Presidência da República, 2018. Disponível em: http://www.planalto.gov.br/ccivil_03/_ato2015-2018/2018/lei/ L13718.htm. Acesso em: 18 fev. 2021. 
BUENO, Samira; LIMA, Renato Sérgio de. (coord.). Anuário Brasileiro de Segurança Pública 2020. São Paulo: Fórum Brasileiro de Segurança Pública, 2020. Disponível em: https://forumseguranca.org.br/anuario-brasileiro-seguranca-publica/. Acesso em: 18 fev. 2021.

CHIERCHIA, Gennaro. Semântica. Tradução Luiz Arthur Pagani, Lígia Negri, Rodolfo Ilari. Campinas: Editora da Unicamp, 2003.

EXPOSIÇÃO na Bélgica traz roupas de vítimas de estupro para romper mito de 'culpa da mulher'. BBC Brasil, 14 jan. 2018. Disponível em: https://www.bbc.com/portuguese/ geral-42643532. Acesso em: 19 fev. 2021.

FARIA, Juliana de; CASTRO, Bárbara. Meu corpo não é seu: desvendando a violência contra a mulher. São Paulo: Companhia das Letras, 2014.

GREIMAS, Algirdas Julien. Semiótica figurativa e semiótica plástica. Tradução I. Assis Silva. In: OLIVEIRA, Ana Claudia de (org.). Semiótica plástica. São Paulo: Hacker Editores, 2004. p. 75-96.

GREIMAS, Algirdas Julien; COURTÉS, Joseph. Dicionário de Semiótica. Tradução A. D. Lima et al. São Paulo: Contexto, 2008.

ONETTO, Fernanda Maria Chacon. Hacia una reconceptualización del acoso callejero. Revista Estudos Feministas, Florianópolis, v. 27, n. 3, 2019. Disponível em: http://dx.doi. org/10.1590/1806-9584-2019v27n357206. Acesso em: 18 fev. 2021.

SOLNIT, Rebecca. A história do caminhar. Tradução Maria do Carmo Zanini. São Paulo: Martins Fontes, 2016.

THINK OLGA. Tudo sobre a lei de importunação sexual. São Paulo: Think Olga; Tribunal Regional Federal da Terceira Região, 2020. Disponível em: https://www.trf3.jus. br/lis/. Acesso em: 18 fev. 2021. 